\title{
Active natural disasters policy in Poland
}

\author{
Zbigniew Piepiora \\ Wrocław University of Environmental and Life Sciences \\ Wrocław, Poland \\ zbigniew.piepiora@up.wroc.pl
}

\author{
Marian Kachniarz \\ Wrocław University of Economics \\ Wrocław, Poland \\ marian.kachniarz@ue.wroc.pl \\ Arkadiusz Babczuk \\ Wrocław University of Economics \\ Wrocław, Poland \\ arkadiusz.babczuk@ue.wroc.pl
}

\begin{abstract}
In the article, there is verified the active natural disasters' policy in the area of Poland. In the examined area, preventing the negative consequences of the extreme phenomena is financed from the central budget and from the budgets of local governments (self-governments). Expenses are assisted by the measures from e.g. foreign states, ecological funds, credits and loans. The hypothesis from the beginning of the article is verified positively: the active natural disaster policy in Poland changed after the great flood in the year 2010. Thus, the answer for the research question of the article is: the natural disasters policy after 2010 is different than the before 2010.The highest level of total expenses for permanent assets serving the water management and for the low water retention was noted in the years after the great flood 2010.
\end{abstract}

Keywords-natural disaster, policy, Poland, counteraction, funding, financing, effects

\section{INTRODUCTION}

In 1997 and 2010 the area of Poland was affected by two great floods. The most devastating inundation the Oder River basin recently happened in the year 1997 and in the Vistula River basin - 2010. The landslides occurred after the flood in 2010 in the Carpathian Mountains. In 2015, the area of Poland was affected by drought.

Floods, droughts, landslides, and tornadoes are examples of natural disasters. These phenomena can be defined, according to the Natural Disaster Act, as an events connected with impacting of nature's forces. Besides mentioned examples, catastrophes are also: atmospheric discharges, storms, seismic activity, intensive rainfalls, extreme temperatures, fires, ice's phenomena on rivers, lakes, water reservoirs and the sea, infestations of insects and diseases of plants, animals and people[15].

The natural disaster can be launched by natural factors: hydrometheorological (e.g. the storm), biological (e.g. the disease), geological (e.g. the seismic activity). It is often a sudden event with tragic effects which causes damages, suffering of people and also changes connected with the affected area[1, 2].
Active natural disasters' policy can be defined as the conscious activity of the government and council authorities, as well as the national and international institutions specialized to minimize the damages caused by natural disasters[7].

The aim of this article is to verifythe hypothesis: the active natural disaster policy in Poland changed after the great flood in the year 2010. The research question of the article is: whether the natural disasters policyafter2010is different thanthe before 2010?

It is worth to notice that the article is part of the research project 'Financing catastrophic damages' chaired by $\mathrm{PhD}$ Zbigniew Piepiora[9].

\section{THE METHODOLOGY}

The data were collected from two databases: the EM-DAT [3] and the BDL - GUS [4]. Then the analysis in spreadsheet was conducted. The currency was changed from Polish Zloty to US dollar. After the analysis the conclusions were drawn.

\section{THE CHARACTERISTICS OF STUDIED AREA}

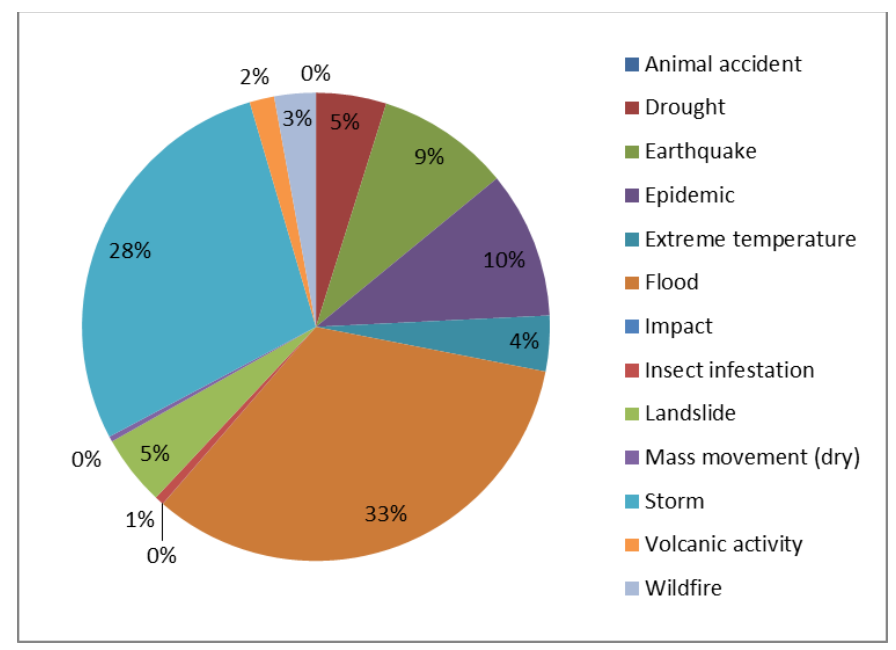

Figure 1. The manifestation of the natural disasters in the area of Poland in the years 1919-2015

Source: Own study on the basis of [3]. 
Poland (The Republic of Poland) is located at the Baltic Sea in the Middle-East Europe. The south part of the examined country has two mountain rages called the Carpathian Mountains (Karpaty) and the Sudetes (Sudety). The main rivers of the state are Vistula (Wisła) and Oder (Odra). The climate of Poland is characterized as a transient of the mesothermal zone.

The manifestation of the natural disasters in the area of Poland in the years 1919-2015 period is presented on the figure 1. As we can see at the figure, floods and storms occurred most often in the examined area. Storms and the floods are hydrometeorological disasters [8, 10, 11].

IV. INSTITUTIONAL AND FINANCIAL ASPECTS OF THE ACTIVE NATURAL DISASTERS POLICY IN THE EXAMINED AREA

On the national, regional and local level the primary meaning in executing the natural disasters policy by the Prime Minister with the Government and the Parliament has the Constitution of the Republic of Poland. The Constitution is completed adequately on the lower levels of the administration by the acts: about the Voivodship Self-Government[14]; about the County Self-Government[13]; about the District SelfGovernment[12]; and about the Voivod and the Government Administration in the Voivodship[16]. According to the article number 228 of the Constitution, in the situations of the extreme danger, such as the natural disaster, if the normal constitutional measures are insufficient, it can be introduced the adequate extraordinary state: the war state, the exceptional state or the natural disaster state [5]. In the case of the last state, the principles of proceeding are précised in the different law - the Act on State of the Natural Disaster [15].

TABLE I. EXPENDITURES FOR PERMANENT ASSETS SERVING THE WATER MANAGEMENT IN THE AREA OF POLAND IN THE YEARS 1998-2014 - DIRECTIONS OF INVESTING (IN ‘000 US DOLLARS INDEXED TO THE YEAR 2014)

\begin{tabular}{|r|l|l|l|l|l|l|l|}
\hline 1. & 2. & 3. & 4. & 5. & 6. & 7. & 8. \\
\hline 1998 & 839585 & 449581 & 102822 & 94581 & 94881 & 90829 & 6891 \\
\hline 1999 & 758926 & 357734 & 99894 & 99705 & 103438 & 89713 & 8441 \\
\hline 2000 & 661674 & 341009 & 78781 & 82407 & 62001 & 91952 & 5524 \\
\hline 2001 & 478205 & 245702 & 61105 & 66724 & 42151 & 58776 & 3747 \\
\hline 2002 & 496348 & 234709 & 74993 & 69868 & 60969 & 49859 & 5949 \\
\hline 2003 & 574527 & 260808 & 75527 & 81256 & 81542 & 66217 & 9176 \\
\hline 2004 & 661217 & 337843 & 84035 & 83739 & 71532 & 75779 & 8289 \\
\hline 2005 & 556263 & 279890 & 94588 & 108694 & 35178 & 36391 & 1521 \\
\hline 2006 & 635590 & 333196 & 113496 & 89584 & 49495 & 41903 & 7916 \\
\hline 2007 & 705957 & 356388 & 115223 & 105740 & 61640 & 51457 & 15509 \\
\hline 2008 & 694669 & 418321 & 122634 & 64671 & 44764 & 42248 & 2032 \\
\hline 2009 & 831052 & 492325 & 191420 & 76094 & 39084 & 28668 & 3462 \\
\hline 2010 & 1014032 & 511499 & 201767 & 125553 & 63492 & 106170 & 5550 \\
\hline 2011 & 869380 & 362710 & 114809 & 151373 & 103924 & 117686 & 18878 \\
\hline 2012 & 740961 & 297559 & 99543 & 104853 & 70640 & 149983 & 18383 \\
\hline 2013 & 784065 & 261576 & 114280 & 184759 & 89510 & 108878 & 25062 \\
\hline 2014 & 965527 & 286372 & 149766 & 210988 & 145796 & 150890 & 21715 \\
\hline total - & 1226797 & 582722 & 189468 & 180059 & 122003 & 135739 & 16804 \\
allyears & 9 & 2 & 6 & 0 & 8 & 8 & 5 \\
\hline
\end{tabular}
1. years, 2. total, 3. intakes and deliveries of water, 4 . building and modernization of water conditionin stations, 4. water reservoirs and stages, 5. regulation and development rivers and streams, 6. levees, 7 . pump stations on breaking downs and depression areas

Expenses for permanent assets serving the water management in Poland in the years 1998-2014 according to directions of investing are presented in the table I. Total expenses for permanent assets serving the water management in Poland in the years 1998-2014 amounted approximately 12.3 billion US dollars indexed to the year 2014.Total expenses were decreasing after the great flood in 1997. The highest level of total expenses and expenditures for levees, and water reservoirs and stages was noted a year after the great flood in 2010.

Effects of investing in the water management in the years 2003-2014 in Poland are presented in the table II. As we can see, data from this table are corresponding with data from the table I. In the period 1998-2013, there were built 216 water reservoirs and $2467 \mathrm{~km}$ levees. Almost 37\% length of levees were built after the great flood 2010.

TABLE II. EFFECTS OF INVESTING IN THE WATER MANAGEMENT IN THE YEARS 1998-2014 IN THE EXAMINED AREA

\begin{tabular}{|c|c|c|c|c|c|c|c|c|}
\hline 1. & 2. & 3. & 4. & 5. & 6. & 7. & 8. & 9. \\
\hline $\begin{array}{l}\text { units of } \\
\text { measure }\end{array}$ & '000 m3 & '000 m3 & $\mathrm{km}$ & unit & '000 m3 & $\mathrm{km}$ & unit & $\mathrm{km}$ \\
\hline 1998 & 404109 & 182460 & 11018 & 84 & 8669690 & 309 & 20 & 777 \\
\hline 1999 & 325131 & 381785 & 8832 & 46 & 682633 & 266 & 11 & 447 \\
\hline 2000 & 300619 & 172532 & 7837 & 52 & 8075070 & 204 & 19 & 205 \\
\hline 2001 & 138945 & 111453 & 6381 & 41 & 24257111 & 163 & 15 & 527 \\
\hline 2002 & 172609 & 101296 & 6582 & 45 & 31725159 & 103 & 25 & 609 \\
\hline 2003 & 142916 & 91834 & 7348 & 18 & 30853335 & 190 & 24 & 859 \\
\hline 2004 & 152414 & 164025 & 7471 & 23 & 5619229 & 243 & 11 & 597 \\
\hline 2005 & 98404 & 146768 & 5576 & 13 & 51867123 & 78 & 6 & 280 \\
\hline 2006 & 100977 & 125048 & 5869 & 7 & 4166906 & 102 & 0 & 222 \\
\hline 2007 & 101297 & 87864 & 5169 & 11 & 5258508 & 95 & 8 & 326 \\
\hline 2008 & 141291 & 104033 & 4979 & 13 & 54994410 & 248 & 11 & 416 \\
\hline 2009 & 160668 & 125738 & 4693 & 6 & 125831 & 60 & 8 & 246 \\
\hline 2010 & 106266 & 127796 & 6271 & 5 & 214093 & 110 & 3 & 299 \\
\hline 2011 & 67075 & 68490 & 5185 & 10 & 4184474 & 305 & 16 & 654 \\
\hline 2012 & 70503 & 76711 & 4028 & 3 & 510327 & 305 & 12 & 385 \\
\hline 2013 & 78366 & 118300 & 4315 & 8 & 4872504 & 156 & 6 & 297 \\
\hline 2014 & 57444 & 71563 & 4043 & 13 & 635664 & 308 & 6 & 374 \\
\hline $\begin{array}{l}\text { total - } \\
\text { allyears }\end{array}$ & 1589175 & 1520919 & 77909 & 216 & 219284674 & 2467 & 151 & 6089 \\
\hline
\end{tabular}

TABLE III. EXPENDITURES FOR PERMANENT ASSETS SERVING THE WATER MANAGEMENT IN POLAND - DIRECTIONS OF FINANCING SOURCES IN THE YEARS 2002-2013 (IN ‘000 US DOLLARS INDEXED TO THE YEAR 2014)

\begin{tabular}{|l|l|l|l|l|l|l|l|l|l|l|}
\hline 1. & 2. & 3. & 4. & 5. & 6. & 7. & 8. & 9. & 10. & 11. \\
\hline 2002 & 496348 & 239242 & 41512 & 36409 & 569 & 3853 & 39448 & 81614 & 20638 & 33064 \\
\hline 2003 & 574527 & 233812 & 37670 & 43141 & 674 & 5983 & 129787 & 78371 & 20490 & 24598 \\
\hline 2004 & 661217 & 258632 & 33077 & 51125 & 54 & 4250 & 132750 & 101178 & 37617 & 42534 \\
\hline 2005 & 556263 & 256604 & 62083 & 27470 & 191 & 6893 & 61131 & 90806 & 25891 & 25194 \\
\hline 2006 & 635590 & 296337 & 43779 & 40489 & 286 & 8162 & 94407 & 72781 & 48822 & 30526 \\
\hline 2007 & 705957 & 342061 & 32953 & 68075 & 38 & 7089 & 95593 & 71135 & 56687 & 32325 \\
\hline 2008 & 694669 & 357585 & 43033 & 51455 & 1190 & 11031 & 82125 & 82293 & 40625 & 25331 \\
\hline 2009 & 831052 & 351232 & 34419 & 42136 & 1507 & 6931 & 173892 & 118004 & 57481 & 45449 \\
\hline 2010 & 1014032 & 435617 & 71291 & 68442 & 215 & 8869 & 192490 & 128045 & 85518 & 23544 \\
\hline 2011 & 869380 & 294186 & 66157 & 73212 & 241 & 13102 & 188484 & 158756 & 52487 & 22753 \\
\hline 2012 & 740961 & 251540 & 69038 & 65351 & 355 & 11239 & 173844 & 128253 & 27284 & 14057 \\
\hline 2013 & 784065 & 246855 & 121670 & 43288 & 388 & 7995 & 198262 & 132342 & 24051 & 9215 \\
\hline $\begin{array}{l}2014 \\
\text { total - } \\
\text { allyears }\end{array}$ & 95295527 & 263117 & 109653 & 85071 & 615 & 9104 & 300323 & 124443 & 53309 & 19891 \\
\hline
\end{tabular}

1. years, 2. total, 3. own measures, 4. measures from the central budget, 5 . measures from the budget of voivodeship, 6 . measures from budgets of counties, 7 . measures from budgets of municipalities, 8. measures from foreign countries, 9. ecological funds, 10. country credits and loans, 11. other measures

Source: Own study on the basis of: $[4,6]$. 
Expenditures for permanent assets serving the water management in the examined area in the years 2002-2013 according to directions of financing sources are presented in the table III. As we can see, the main source of expenses were own measures of investors. From these source, there were financed $40 \%$ of total expenditures in the examined period which totally exceeded 9.5billion US dollars.

Expenses for water management were co-financed from ecological funds. One of these funds is the Fund for Environmental Protection and Water Management. Charges and incomes to this fund in Poland in the years 2002-2014 amounted over 5.4 billion US dollars. As we can see in the table IV, incomes from charges for air protection and climate were the main part of total incomes and amounted approx.2.4billion US \$.

TABLE IV. CHARGES AND INCOMES TO THE FUND FOR ENVIRONMENTAL PROTECTION AND WATER MANAGEMENT IN POLAND IN THE YEARS 2002-2014 (IN '000 US DOLLARS INDEXED TO THE YEAR 2014)

\begin{tabular}{|l|l|l|l|l|l|l|l|l|c|}
\hline \multicolumn{1}{l|}{} & 2. & 3. & 4. & 5. & 6. & 7. & 8. & 9. & 10. \\
\hline 2002 & 0 & 0 & 0 & 0 & 0 & 0 & 0 & 0 & 0 \\
\hline 2003 & 22718 & 519066 & 173243 & 236851 & 78476 & 0 & 30495 & 47678 & 4132 \\
\hline 2004 & 28755 & 542918 & 148661 & 280166 & 83755 & 0 & 30336 & 39353 & 12847 \\
\hline 2005 & 20502 & 426886 & 121630 & 211590 & 61342 & 5 & 32319 & 23290 & 5942 \\
\hline 2006 & 36126 & 493505 & 139331 & 254956 & 82850 & 7 & 16362 & 7169 & 1482 \\
\hline 2007 & 20091 & 530873 & 143953 & 259016 & 107263 & 25 & 20616 & 8993 & 1113 \\
\hline 2008 & 24856 & 569718 & 137807 & 250675 & 160116 & 1 & 21119 & 8417 & 1051 \\
\hline 2009 & 20419 & 551652 & 132155 & 193014 & 207816 & 0 & 18666 & 19493 & 1288 \\
\hline 2010 & 13247 & 552943 & 129859 & 205171 & 203234 & 2 & 14676 & 24122 & 1720 \\
\hline 2011 & 19276 & 532117 & 128475 & 211758 & 186113 & 50 & 5770 & 22821 & 1822 \\
\hline 2012 & 14113 & 485165 & 125114 & 192422 & 158393 & 0 & 9235 & 16669 & 3530 \\
\hline 2013 & 8628 & 227432 & 58415 & 87853 & 73612 & 0 & 7551 & 12270 & 2465 \\
\hline 2014 & 7230 & 413307 & 116797 & 162615 & 114414 & 0 & 19480 & 9263 & 1834 \\
\hline $\begin{array}{l}\text { total - } \\
\text { allyears }\end{array}$ & 228732 & 5432274 & 1438645 & 2383473 & 1402972 & 89 & 207146 & 230274 & 37392 \\
\hline 1.
\end{tabular}

1. years, 2. level of measures at beginning of the year, 3. total incomes, 4. incomes from charges for wastewater management and water protection, 5 . incomes from charges for air protection and climate, 6 . incomes from charges for waste management, 7. incomes from charges for other fields, 8. other incomes, 9. administered penalties, 10 . incomes from penalties

Source: Own study on the basis of: $[4,6]$.

Investing expenses for the low water retention in Poland in the years 2003-2014 according to investing directions are presented in the table V. As we can see, investing expenditures for man-made water reservoirs exceeded 167 million US dollars. Total investing expenses for the low water retention amounted approximately 245 million US \$. The highest levels of total expenses were noted after the great flood in 2010.

Investing expenses for the low water retention in Poland in the years 2003-2014 according to financing sources are presented in the table VI. As we can see, expenses were financed mainly from structural funds of the European Union and from the other sources.
TABLE V. INVESTING EXPENSES FOR THE LOW WATER

RETENTION IN POLAND - DIRECTIONS OF INVESTING IN THE YEARS 2003-2014 (IN ‘000 US DOLLARS INDEXED TO THE YEAR 2014)

\begin{tabular}{|c|c|c|c|c|c|c|c|}
\hline years & total & $\begin{array}{c}\text { man- } \\
\text { madewaterrese } \\
\text { rvoirs }\end{array}$ & $\begin{array}{l}\text { indepen } \\
\text { dent } \\
\text { staging } \\
\text { structure } \\
\text { s and } \\
\text { water } \\
\text { intakes } \\
\text { on } \\
\text { primary } \\
\text { water- } \\
\text { races }\end{array}$ & $\begin{array}{l}\text { independ } \\
\text { ent } \\
\text { staging } \\
\text { structures } \\
\text { and water } \\
\text { intakes } \\
\text { on secon } \\
\text { dary } \\
\text { water- } \\
\text { races }\end{array}$ & $\begin{array}{l}\text { stagingla } \\
\text { kes }\end{array}$ & $\begin{array}{c}\text { fishpo } \\
\text { nds }\end{array}$ & $\begin{array}{c}\text { othe } \\
r\end{array}$ \\
\hline 2003 & $\begin{array}{c}2114 \\
2 \\
\end{array}$ & 13912 & 2064 & 76 & 62 & 2651 & $\begin{array}{c}237 \\
7 \\
\end{array}$ \\
\hline 2004 & $\begin{array}{c}2232 \\
7 \\
\end{array}$ & 16697 & 2098 & 22 & 290 & 982 & $\begin{array}{c}223 \\
7 \\
\end{array}$ \\
\hline 2005 & 7271 & 4957 & 544 & 69 & 88 & 1241 & 373 \\
\hline 2006 & $\begin{array}{c}1923 \\
5\end{array}$ & 15255 & 1552 & 44 & 292 & 1709 & 383 \\
\hline 2007 & $\begin{array}{c}2321 \\
1 \\
\end{array}$ & 15186 & 4863 & 140 & 969 & 1149 & 904 \\
\hline 2008 & $\begin{array}{c}1256 \\
1\end{array}$ & 6697 & 2476 & 6 & 81 & 1524 & $\begin{array}{c}177 \\
8\end{array}$ \\
\hline 2009 & $\begin{array}{c}1385 \\
3 \\
\end{array}$ & 10342 & 1895 & 0 & 15 & 1349 & 151 \\
\hline 2010 & $\begin{array}{c}1761 \\
9\end{array}$ & 9426 & 4142 & 3 & 2366 & 1515 & 1 \\
\hline 2011 & $\begin{array}{c}2932 \\
3 \\
\end{array}$ & 21251 & 4834 & 160 & 751 & 1392 & 934 \\
\hline 2012 & $\begin{array}{c}1768 \\
3 \\
\end{array}$ & 10322 & 3844 & 7 & 977 & 1069 & $\begin{array}{c}146 \\
4 \\
\end{array}$ \\
\hline 2013 & $\begin{array}{c}2826 \\
7 \\
\end{array}$ & 21786 & 3735 & 784 & 0 & 597 & $\begin{array}{c}136 \\
5\end{array}$ \\
\hline 2014 & $\begin{array}{c}3265 \\
5 \\
\end{array}$ & 21283 & 7933 & 61 & 83 & 2152 & $\begin{array}{c}114 \\
1 \\
\end{array}$ \\
\hline $\begin{array}{l}\text { total } \\
- \\
\text { allye } \\
\text { ars } \\
\end{array}$ & $\begin{array}{c}2451 \\
47\end{array}$ & 167115 & 39980 & 1372 & 5973 & 17330 & $\begin{array}{c}131 \\
09\end{array}$ \\
\hline
\end{tabular}

TABLE VI. INVESTING EXPENSES FOR THE LOW WATER RETENTION IN POLAND IN THE YEARS 2003-2014- SOURCES OF FINANCING (IN '000 US DOLLARS INDEXED TO THE YEAR 2014)

\begin{tabular}{|c|c|c|c|c|c|c|c|}
\hline & & $\begin{array}{c}\text { from } \\
\text { budget } \\
\text { of } \\
\text { Voivo } \\
\text { years }\end{array}$ & $\begin{array}{c}\text { from Fund } \\
\text { for } \\
\text { Environment } \\
\text { al Protection } \\
\text { and Water } \\
\text { Management }\end{array}$ & $\begin{array}{c}\text { from } \\
\text { Fund for } \\
\text { protectio } \\
\text { n rural } \\
\text { areas }\end{array}$ & $\begin{array}{c}\text { from } \\
\text { from } \\
\text { structuralfun } \\
\text { ds }\end{array}$ & $\begin{array}{c}\text { cudgets of } \\
\text { self- } \\
\text { governmen } \\
\text { ts }\end{array}$ & other \\
\hline 2003 & 21142 & 5936 & 1562 & 1612 & 0 & 1374 & $\begin{array}{c}1065 \\
7\end{array}$ \\
\hline 2004 & 22327 & 8187 & 6439 & 934 & 0 & 965 & 5801 \\
\hline 2005 & 7271 & 1999 & 2351 & 376 & 0 & 755 & 1791 \\
\hline 2006 & 19236 & 5121 & 5856 & 1925 & 0 & 3143 & 3191 \\
\hline 2007 & 23211 & 2609 & 4024 & 310 & 0 & 5390 & 1701 \\
\hline 2008 & 12561 & 3054 & 2296 & 511 & 2850 & 1760 & 2090 \\
\hline 2009 & 13853 & 855 & 2807 & 569 & 3527 & 2965 & 3131 \\
\hline 2010 & 17619 & 2217 & 91 & 905 & 9245 & 1843 & 2488 \\
\hline 2011 & 29323 & 3968 & 3971 & 686 & 14711 & 3278 & 3395 \\
\hline 2012 & 17683 & 3182 & 1737 & 984 & 152 & 2947 & 8834 \\
\hline 2013 & 28267 & 4808 & 1674 & 1513 & 16622 & 1902 & 1837 \\
\hline
\end{tabular}


Effects of investing in the low water retention are presented in the table VII. The range of objects in Poland in the years 2003-2014 amounted 6750. Total increasing capacity in the examined period exceeded $87061 \mathrm{~m}^{3}$.

TABLE VII. EFFECTS OF INVESTING IN THE LOW WATER RETENTION - THE RANGE OF OBJECTS IN POLAND IN THE YEARS 2003-2014

\begin{tabular}{|c|c|c|c|c|c|c|c|c|c|c|c|}
\hline \multirow[t]{2}{*}{ years } & \multirow{2}{*}{$\begin{array}{l}\begin{array}{l}\text { obje } \\
\text { cts }\end{array} \\
1 . \\
\end{array}$} & \multirow{2}{*}{ 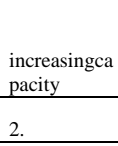 } & \multicolumn{2}{|c|}{$\begin{array}{l}\text { staging } \\
\text { of lakes }\end{array}$} & \multicolumn{2}{|c|}{$\begin{array}{c}\text { artificialwaterres } \\
\text { ervoirs }\end{array}$} & \multirow{2}{*}{$\begin{array}{c}\begin{array}{c}\text { fishpo } \\
\text { nds }\end{array} \\
1 . \\
\end{array}$} & \multicolumn{2}{|c|}{$\begin{array}{l}\text { stagingstruct } \\
\text { ures }\end{array}$} & \multirow{2}{*}{$\begin{array}{l}\begin{array}{l}\text { oth } \\
\text { er }\end{array} \\
1 . \\
\end{array}$} & \multirow{2}{*}{$\begin{array}{l}\text { surfac } \\
\text { e of } \\
\text { irrigat } \\
\text { ion }\end{array}$} \\
\hline & & & 1 & 2. & 1. & 2 & & 2. & 1. & & \\
\hline 2003 & 253 & 10824 & 1 & $\begin{array}{c}293 \\
7 \\
\end{array}$ & 62 & 6185 & 130 & 1702 & 60 & 0 & 1517 \\
\hline 2004 & 162 & 13162 & 2 & $\begin{array}{c}597 \\
4 \\
\end{array}$ & 52 & 6348 & 69 & 841 & 39 & 0 & 1049 \\
\hline 2005 & 171 & 4943 & 1 & $\begin{array}{c}199 \\
7 \\
\end{array}$ & 34 & 1928 & 84 & 1018 & 52 & 0 & 718 \\
\hline 2006 & 665 & 9568 & 2 & $\begin{array}{c}171 \\
7 \\
\end{array}$ & 42 & 6068 & 567 & 1783 & 54 & 0 & 1356 \\
\hline 2007 & 292 & 5940 & 3 & 793 & 92 & 4516 & 55 & 631 & 142 & 0 & 808 \\
\hline 2008 & 249 & 4751 & 2 & 155 & 104 & 1686 & 82 & 2910 & 48 & 13 & 285 \\
\hline 2009 & 171 & 6204 & 1 & $\begin{array}{l}0 \\
\end{array}$ & 62 & 1526 & 80 & 4678 & 16 & 12 & 830 \\
\hline 2010 & 3604 & 7456 & 6 & $\begin{array}{c}457 \\
9 \\
\end{array}$ & 3503 & 1126 & 60 & 1751 & 34 & 1 & 8935 \\
\hline 2011 & 377 & 6821 & 3 & $\begin{array}{c}155 \\
6 \\
\end{array}$ & 90 & 4188 & 81 & 1077 & 200 & 3 & 785 \\
\hline 2012 & 245 & 11475 & 9 & $\begin{array}{c}493 \\
8\end{array}$ & 113 & 5206 & 87 & 1331 & 29 & 7 & 924 \\
\hline 2013 & 370 & 3285 & 0 & 0 & 141 & 2783 & 40 & 502 & 178 & 11 & 661 \\
\hline 2014 & 191 & 2633 & 0 & 0 & 96 & 2045 & 58 & 589 & 26 & 11 & 2472 \\
\hline $\begin{array}{l}\text { total } \\
- \\
\text { allye } \\
\text { ars } \\
\end{array}$ & 6750 & 87061 & $\begin{array}{l}3 \\
0\end{array}$ & $\begin{array}{c}246 \\
45\end{array}$ & 4391 & 43604 & 1393 & $\begin{array}{c}1881 \\
1\end{array}$ & 878 & 58 & 20340 \\
\hline
\end{tabular}

Source: Own study on the basis of: $[4,6]$

\section{CONCLUSIONS}

After the analysis of active natural disasters policy in Poland, the following conclusions can be drawn.

The hypothesis from the beginning of the article was verifiedpositively: the active natural disasters policy in Poland changed after the great flood in the year 2010. Thus, the answer for the research question of the article is: the natural disasters policyafter2010is different thanthe before 2010 .

In the examined area, the active natural disasters policy is financed from the central budget and budgets of local (selfgovernments). Expenditures are supported by means, among others, from foreign, environmental funds, loans and advances.

Expenses for permanent assets serving the water management in Poland in the years 1998-2014 according to directions of investing amounted 12.3 billion US dollars indexed to the year 2014.

Total expenses were decreasing after the great flood in 1997. The highest level of total expenses and expenditures for levees, and water reservoirs and stages was noted a year after the great flood in 2010, in the year 2010 and next years.

In the period 1998-2013, there were built 216 water reservoirs and $2467 \mathrm{~km}$ levees. Almost 37\% length of levees were built after the great flood in 2010 .
The main source of expenses were own measures of investors. From these source, there were financed $40 \%$ of total expenditures in the examined period which totally exceeded 9.5 billion US dollars.

Incomes from charges for air protection and climate were the main part of total incomes of the Fund for Environmental Protection and Water Management and amounted approx. 2.4 billion US \$.

Investing expenditures for man-made water reservoirs exceeded 167 million US dollars. Total investing expenses for the low water retention amounted approximately 245 million US \$. Expenses were financed mainly from structural funds of the European Union and from the other sources.The highest levels of total expenses were noted after the great flood in 2010 .

The range of objects of the low water retention in Poland in the years 2003-2014 amounted 6750. Total increasing capacity in the examined period exceeded $87061 \mathrm{~m} 3$.

\section{REFERENCES}

[1] Abbott P. L., Natural disasters, San Diego State University, San Diego 2009.

[2] Alexander D., Natural disasters, Wydawnictwo Springer Science \& Business, Berlin 1993.

[3] EM-DAT: OFDA/CRED (2012), http://www.emdat.be (31.10.2015).

[4] GUS, Bank Danych Lokalnych, http://www.stat.gov.pl/bdl/app/strona.html?p_name=indeks, 30.10.2015.

[5] Konstytucja Rzeczypospolitej Polskiej (1997), Dz.U. 1997, nr 78 poz. 483.

[6] MyBank.pl, http://kursy-walut-kupno-sprzedaz.mybank.pl/, 31.10.2015.

[7] Z. Piepiora, Ekonomiczne aspekty lokalnej polityki przeciwdziałania skutkom katastrof naturalnych, wyd. Zbigniew Piepiora, Kowary 2012.

[8] Z. Piepiora, The law and economic aspects of counteracting the natural disasters' effects in the area of Poland, w: Корецкий Н. X. (red.) Сobpeменный НаучныйВестник, No 4 (116) 2012, Wydawnictwo Руснаучкнига, Коллектив авторов, Белгород 2012, ISSN 1561-6886, s. 104-119.

[9] Z. Piepiora, A. Babczuk, M. Kachniarz, Financing the Counteraction of Natural Disasters' Effects in Lower Silesian Voivodeship, DOI 2991-1001, http://www.atlantis-press.com/php/pub.php?publication=icmemi$15 \&$ frame $=$ http\%3A//www.atlantis-press.com/php/paperdetails.php\%3Ffrom\%3Dsession+results\%26id\%3D16211\%26querystr \%3Did\%253D304, Atlantis Press 2015, p. 215-221.

[10] J. Rodzik, Wpływ deszczów ulewnych i roztopów na rozwój wąwozu lessowego, w: Landform Analysis, Vol. 8, wyd. Stowarzyszenie Geomorfologów Polskich, Poznań 2008.

[11] U. Somorowska, Wzrost zagrożenia suszą hydrologiczną w różnych regionach geograficznych Polski w XX wieku, w: Prace i Studia Geograficzne, tom 43, Uniwersytet Warszawski, Warszawa, 2009, s. 97114.

[12] Ustawa z dnia 8 marca 1990 roku o samorządzie gminnym, Dz. U. z 1990 r. 142, poz. 1591 z późniejszymi zmianami.

[13] Ustawa z dnia 5 czerwca 1998 r. o samorządzie powiatowym, Dz. U. $1998 \mathrm{nr} 91$ poz. 578 z późniejszymi zmianami.

[14] Ustawa z dnia 5 czerwca 1998 r. o samorządzie województwa, Dz. U. $1998 \mathrm{nr} 91$ poz. 576 z późniejszymi zmianami.

[15] Ustawa z dnia 18 kwietnia 2002 r. o stanie klęski żywiołowej Dz. U. $2002 \mathrm{nr} 62$ poz. $558 \mathrm{z}$ późniejszymi zmianami.

[16] Ustawa z dnia 23 stycznia 2009 r. o wojewodzie i administracji rządowej w województwie, Dz. U. z 2009 r. nr 31, poz. 206. 